\title{
Islamic Boarding School International Program in View of Integrated Marketing Communication Syariah (Study on Darunajah Islamic Boarding School)
}

\author{
$1^{\text {st }}$ Barliana Lukitawati ${ }^{1}, 2^{\text {nd }}$ Riris Aishah ${ }^{2}$ \\ \{berliana.lukitawati@uinjkt.ac.id ${ }^{1}$,riris.aishah@uinjkt.ac.id ${ }^{2}$ \} \\ UIN Syarif Hidayatullah Jakarta ${ }^{1,2}$
}

\begin{abstract}
Many educational institutions have international standard programs to improve the quality of their education. In this study, the authors took the Darunajah Islamic Boarding School as the research subject. Considering this Islamic boarding school has many international standard programs. However, international labels are neither heard nor seen in their marketing activities. With the research object of sharia integrated marketing communication, it was found that this international standard program was based as a form of building the widest possible network. In the marketing mix, this emphasizes the element of physical evidence, as evidence recognition of foreign countries without having to write an international boarding school in its promotion. This is more capable of building trust than massive self-promotion. People will hear through word of mouth as evidence. So that physical evidence becomes a means of promotion through the help of outside parties/other institutions.
\end{abstract}

Keywords: Integrated marketing communication, islamic boarding school, international program.

\section{Introduction}

In the world of education, topics such as curriculum, learning methods, costs to school rules are always a consideration for parents in choosing a school for their child. More and more parents now understand the importance of the role of education for their children to compete at the global level. This can be seen from the rise of various international schools that use international words in their promotions. Although sometimes the international meaning has not been carried out as it should. The proliferation of international schools has also occurred in Islamic boarding schools, not only public schools. Considering that generally international programs are one of the marketing strategies in attracting the interest of prospective parents in choosing the right school or Islamic boarding school as expected. In the literature it is said that: Of course this is reasonable, considering that international standard programs will be able to overcome competition in the world of practitioners who will be connected to the world interaction system. There are so many world trade/economic systems that ultimately require academics to become qualified practitioners with the demands of global needs. Foreign language skills, Information and technology skills, and so on [1].

Thus, from this explanation, the author can convey that one of the factors in choosing an 
international school is the increasing understanding of the importance of education with an international standard curriculum today. Regardless of the existence of lifestyle factors or existing trends, the following are facts and advantages that are generally owned by international schools.

The definition of International Standard School according to the Ministry of National Education: International Standard Schools/Madrasahs are "Schools/Madrasahs that have met all National Education Standards and are enriched concerning the educational standards of one member country of the Organization for Economic Cooperation and Development (OECD) and/or other developed countries that have certain advantages in the field of education. So that they have competitiveness in international forums". According to the ministry of national education, the definition of an International Standard School (SBI) is an educational unit organized using the National Education Standards (SNP) and enriched with the standards of a member country of the Organization for Economic Cooperation and Development (OECD) or other developed countries. According to the regulation of the minister of national education (permendiknas) No. 78 of 2009, concerning the implementation of International Standard Schools at the primary and secondary education levels Article 1 Paragraph 8 states that "International standard schools here in after abbreviated as SBI are schools that have fulfilled all SNPs enriched with certain quality advantages. originating from member countries of the Organization for Economic Cooperation and Development (OECD) or other developed countries [2]."

Based on the description above, it can be explained that the International Standard School (SBI) is a national school which is the same as schools in general in Indonesia, but the International Standard School combines two curricula (national and international) intending to produce internationally certified graduates. In a study, it was said that there are several reasons why schools hold international standard programs, including, so that students can compete in the era of globalization, the demands of society for international quality schools [3].

In this study, the author took one of the research subjects, namely Islamic boarding schools with various international standard programs, one of which was Darunajah. Darunnajah Islamic Boarding School is a private (non-government) Islamic educational institution. Initiated in 1942, Islamic Boarding School was founded on April 1, 1974, with boarding education and intensive Arabic and English teaching. And using an integrated curriculum system located on Ulujami Raya street number 86. Ulujami Village Pesanggrahan district, South Jakarta City. DKI Jakarta Province. With an integrated curriculum system, boarding education, and intensive Arabic and English teaching. Darunajah is very advantageous, where is located on the outskirts of the capital.

Several years ago there was a phenomenon of the international standard school program (SBI), which was abolished by the government. It is suspected that some schools use this program as an element of pressure to raise costs so that they can be more expensive. Pesantren, have never claimed their institutions with international labels or so on. However, it is the pesantren that have been running international level programs for a long time. For example, the Darunnajah Islamic Boarding School. The Modern Islamic Boarding School, which is located in the capital and has 17 branches throughout Indonesia, is often involved with international programs. The internationality of pesantren even begins at an early age from their educational programs. On their curriculum and lesson syllabus. The majority are written and delivered in International languages. Especially Arabic and English. Darunnajah uses the Oxford English system as their official program, although some still use the Berlitz system. Arabic and English are also the daily languages of students in communicating.

Many students at the pesantren, including Darunnajah, come from abroad, such as 
Malaysia, Thailand, Singapore, the Philippines, and so on. Recorded at the Ministry of Religion, around 13,000 active students are foreign citizens. Around 50 students study at the Darunnajah Islamic boarding school. In terms of visits from international figures, this pesantren even exceeds schools that claim to be of international standard. This boarding school is a subscription for state guests who want to see how the education system in a pesantren is. Presidential friends from dozens of countries regularly visit this lodge every year. Countless ambassadors of friendly countries visited this lodge. Even world-class officials and figures such as Tony Blair, Yusuf Al Qordhawi, Imam of the Grand Mosque, Masjidil Aqsa, Chancellor of world universities such as Medina, Vice President of Afghanistan, Yusuf Islami and Advisor Barrack Obama and others who cannot be mentioned entirely. Some not only visited but also invited Darunnajah to work together in the field of education. Presidential friends from dozens of countries regularly visit this lodge every year. Countless ambassadors of friendly countries visited this lodge. Even world-class officials and figures such as Tony Blair, Yusuf Al Qordhawi, Imam of the Grand Mosque, Al-Aqsa Mosque, Chancellors of world universities such as Medina, Vice President of Afghanistan, Yusuf Islami and Barrack Obama Advisors and others who cannot be mentioned entirely. Some not only visited but also invited Darunnajah to work together in the field of education.

In terms of cooperation in educational programs with foreign institutions, Islamic boarding schools also carve a record that is not less. Recognition of Darunnajah Islamic Boarding School alumni who graduated from various institutions in Middle Eastern countries such as Al Azhar Cairo, Medina Univ in Saudi, International Islamic University Islamabad, and Malaysia. Dozens of alumni each year are dispatched to study at leading universities in the world. International programs are not only enjoyed by pesantren alumni, but also students from the time they are boarding, such as student exchanges, teacher exchanges, and so on. Many delegate programs for international events are held in this institution. Not only cooperation with institutions in neighboring countries such as Malaysia and Thailand, but with institutions in countries in the Middle East such as Saudi, Egypt, Qatar or even Australia, even Europe such as the UK. However, the world of pesantren has never used an excuse for pesantren to label their pesantren with the label "International Islamic Boarding School", and never used it as an excuse to raise the cost of their education high, it is proven that pesantren until now remains an institution that is affordable by all people [4].

Thus, it can be seen how pesantren marketing communication in the form of integrated marketing communication (IMC) can be carried out well for this international standard program. Although these marketing communication activities are not accompanied by international labels. Meanwhile, many schools use the label to attract students' interest and increase the price of their education. So that this is the basis for the author to conduct research related to IMC at an international standard program at the Darunajah Islamic Boarding School. Without international labels, Islamic boarding schools are able to be marketable with an extensive network. How is the review of integrated marketing communication in international standard programs in Islamic boarding schools? 


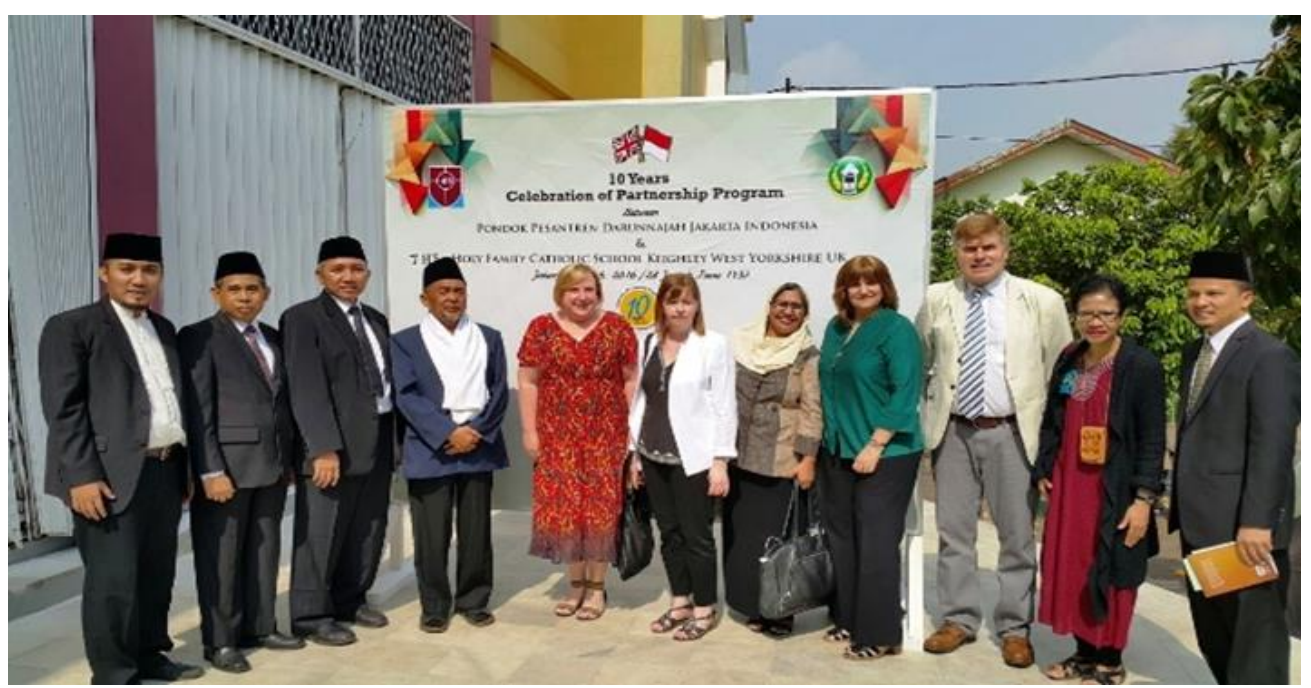

Fig. 1. Partnership program.

\section{Literature Review}

As for Integrated Marketing Communication (IMC), or also known as the marketing mix. There are views of experts, where the marketing mix in sharia marketing is still experiencing debate and complementing each other. But in general, there are guidelines in the formulation of several experts. Among other things related to the product, price, place, promotion, people, and physical evidence. This instrument supports marketing.

State of The Art:

1. In Felinda Karela's research, entitled School Marketing Strategy in Increasing Student Interest Based on the Delta Model 2020. Examines how marketing strategies increase student acceptance, how they are implemented, and how they are evaluated. However, this study did not examine related international standard programs in terms of sharia integrated marketing [5].

2. In Seviyenti Fikroh's research entitled Darul Hikam International School Marketing Communication (Case Study of Darul Hikam International School in Achieving the Target Number of New Students) 2016. The purpose of this paper is: To examine the marketing communications carried out by SIDH in achieving the target number of new students and to examine the relationship that SIDH has built with other institutions in achieving the target number of new students. However, this study does not examine related international standard programs in terms of sharia integrated marketing [6]. 
3. In Aditia Pradito's research entitled Educational Marketing Strategy in improving the image of educational institutions 2016. The focus of this research is on how educational services improve the image, how the strategy is in improving the image, and how the impact and marketing implications are. However, this study did not examine the international standard program in terms of sharia integrated marketing [7].

\section{Methodology}

I used descriptive with qualitative approach. With case study design. And for the data collection techniques, uses literature. And also internet searching, interviews, observation, and documentation. Data analysis techniques by intensively and continuously through several steps [8]. With data collection, data reduction, data display, and data conclusion. Concerning the communication strategy, Argenti, Howell, and Beck (2005) say that define strategic communication as aligned with the company's overall strategy to enhance its strategic positioning [9].

Regarding marketing communications, Philip Kotler and Keller said that: "Marketing efforts can be done by communicating either directly or indirectly so that consumers get the information they need. Marketing communication has a meaning as an activity as a form of effort to disseminate and convey information, influence, and or remind the target market to buy and consume a product or service. In the sense of being loyal to the products offered" [10].

From the description above, it can be seen that marketing communication as an effort of marketing activities is carried out directly or indirectly according to consumer needs. To disseminate, convey information, influence or remind the target market to buy and consume a product or service. This is where integrated marketing communications are needed and known as IMC which combines several forms of marketing to be unified and integrated to expand the network and attract consumers. In addition, it is further described in a research conclusion related to integrated marketing communication (IMC) that:

The priority in marketing communication activities is strategic planning, the right strategy will lead the company to achieve company goals. Various marketing strategies will help marketers to market their products, one of which is integrated marketing communications (IMC). Of course, the purpose of marketing communication is not far from the basic goal of marketing communication, namely sales success through attracting consumer buying interest, but IMC is slightly different because it is integrated with technological advances and other elements in promotional activities. Integrated marketing communication has five elements, namely advertising, sales promotion, public relations, personal selling, and even direct and online marketing [11].

In the sharia marketing mix (IMC) there are views of experts, where the marketing mix in sharia marketing is still experiencing debate and complementing each other. But in general, there are guidelines in the formulation of several experts. Among other things related to the product, price, place, promotion, people, and physical evidence. This instrument supports marketing. As for a sharia marketing book literature, by Asnawi and Asnan Fanani, there are Abdullah's findings related to the integrated marketing mix such as conforming (conformity) refers to the product, character (character) and conscience (conscience) refers to the nature of human beings. commitment (commitment) refers to aspects of the process. The Islamic marketing mix is broadly presented as shown below (Nur Asnawi and M. Asnan Fanani, Sharia Marketing [12]. 


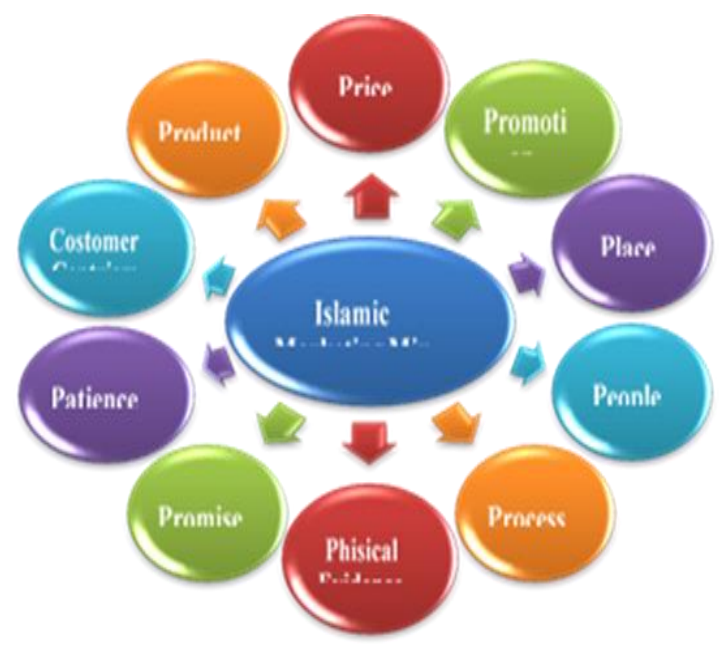

Fig. 2. Islamic marketing mix.

1. The products

As part of the marketing mix elements. Explicity the products that are prohibited by the Quran and Sunnah of the prophet are animal blood, carrion, pork, alcoholic beverages, the use of interest in financial and banking practice, prostitution. (Surah al-Baqarah: 168) If it is related to research, the international standard program at this pesantren is not classified as a service product in the form of a prohibited program. This international standard program is to improve the quality of education to a global level by establishing the widest possible relationship. Even the Prophet recommended friendship. This program supports the establishment of friendships with other countries.

2. The price

Price is one of mixed marketing in Islam. It is prohibited to make low prices below the market. Prohibit of maisiror, receive gain but not working, change the prices of product but not being changed by quality or quantity of the product. It is forbidden to deceive customers to make profits, The discrimination for the price in the business market, making lies persuasion or propaganda by using gambling media._t is prohibited in hoarding and controlling the price which makes scarcity of stock. It is prohibited in hoarding of product stock in Islam religion. If it is related to this research, in terms of price, this pesantren is known to have an affordable price. Although there are international standard programs. This is not an excuse to raise the price of education. The words of the Messenger of Allah regarding this policy is: don't ever make competition with your brother unhealthy of sales. (quote from hadits Bukhari Muslim) 3. The place 
Is one of the marketing mixes, which means the element the place can determine distribution of business. And also determine the success of an effective marketing strategy. Including people, companies, equipment involved in the marketing process. It must be transparent and make satisfied customers.

As an element of the marketing mix, it means distribution and place of business that determines the success of an effective marketing strategy. In Islam, the existence of people, equipment, companies involved in the marketing process must be transparent and satisfy the customers. Hadith said, there is prohibited for city dwellers to be commercial intermediaries for the people who live in the village far from the city. The messenger of Allah said it is not permissible for city dwellers to become commercial intermediaries for people in the village. Let people get Allah's sustenance from one to another ( quoted from HR Bukhari). There is a suggestion for producers for mapping places to support the marketing program.

A place for running business transactions was the market. It is only a place to establish and exchange friendships with fellow traders. Including the mission of trading in the style of the prophet Muhammad. Basically in Islam, as stated in hadith the process for distribution strategy is a mechanism delivering product or process of delivering without any obstacles from parties who only want to make profits due to ignorance. For example when the traders had a transaction of their harvest from farmers in a village far from the information market. Then they sell to the city at a high price and the traders got very much profit. This is the talaqqi al Ghabbunand, and it is prohibited in Islam. This prohibition is to protect farmers and consumers. Traders can take reasonable prices through the cost of transportation and service fees.

If it is associated with this research, then the location and distribution are very strategic, easy to reach, for students. The location of the pesantren is very advantageous because it is on the outskirts of the capital, which facilities communication both with government agencies and with the wider community. With affordable prices for the community. And do not take advantage of the price increase for the existence of such a strategic and easy place and distribution.

4. The promotion

Is one of the activities in marketing which introduce and offer some products. For making promotion, it is forbidden to provide excessive communication. Muhammad saw himself in promoting traded goods never gave excessive communication, instead, he provided information as it was so that buyers would get clear product information before deciding to buy it. The effect of excessive promotion will make disappointment for the customer. The negative information will be accepted by the customer through word-of-mouth media. The implication is that consumer trust is lost to less honest marketers.

In connection with this research, the Darunajah Islamic boarding school carries out promotional activities without exaggerating the reality that exists in the boarding school. Even international labels are not used, although international activities have long been and are widely used in this Islamic boarding school. Such as student and teacher exchange cooperation, recognition as an international standard school from many countries, visits by state officials, and so on. This evidence will later become promotional media by itself. Without having to label with an international designation. Remembering the evidence will make people believe more without having to go overboard in the promotion.

5. The people (human)

Humans play an interesting action in the practice of marketing to producers and consumers. Marketers must serve and pay attention, protect their business partners, consumer, and society. And also be honest and responsible for the products. And be careful too, in running a business. Rasulullah saw prohibited dubious products, speculative practices, fraudulent activities, or 
gharar transactions.

There are ethics in Islam, that marketers must have a sense of responsibility, in four categories:

In Islamic ethics, marketers must show a sense of responsibility in 4 categories: have a responsibility to Allah Swt, have a responsibility to the community c. Have a Responsibility to the community, have responsibility for own welfare, have the responsibility to the environment. Hadith says: "Avoid services and products which prohibited in Islam expressly, avoid products which are doubt, avoid lies buying and selling, avoid transaction fraudulent, avoid the element of speculation (gharar)." (HR Bukhari)

If it is related to this research, the pesantren marketers are honest in advertising according to the existing reality. Educators are always improved in quality. One of them is a comparative study with other countries or a teacher exchange program, which is part of an international standard program. To improve the quality of education through educators.

Marketers run businesses must be responsible and be honest to their products. They have to protect and pay attention to suppliers, employees, society, consumers.

Marketers must be careful in running a business, even Rasulullah saw prohibition to run business with the product prohibited in Islam. Marketers must be honest in running a business. Even in selling or buying transactions. Also, avoid fraudulent business and speculative business or gharar in terms of Islam.

And in Ethics, Islam teaches marketers must have responsible to Allah Swt, to the community, for their welfare, and to the environment. In hadith, there is a rule for avoiding products prohibited in Islam expressly, also transactions or products in doubt. Marketers must be honest in selling and buying. Avoid fraudulent transactions and avoid speculation of transaction/ gharar. (HR Bukhari)

6. The process

As elements include procedures, mechanisms, the flow of treatment in serving. Process, means there are products and services. In process of serving products, a marketer must be honesty as a value and give respect, giving fairness, open to all communities.

In the practice carried out by the Messenger of Allah, it is a form of service that is polite, friendly, and provides information.

The process in the context of a service business must be understood by marketing actors, especially an understanding of the nature of the service itself which includes: services cannot be seen and felt before consumers buy or are directly involved in the process, services are very dependent on who, what, how the business is also delivered, services can not be separated from the buyer, and services also cannot be stored for the future.

If it is related to this research, it can be explained that the process that occurs in international standard programs depends on the type of program. For example, students in Islamic boarding schools, including Darunnajah, come from abroad, such as Malaysia, Thailand, Singapore, the Philippines, and so on. Recorded at the Ministry of Religion, around 13,000 active students are foreign citizens. Around 50 students study at the Darunnajah Islamic boarding school. All processes are made easy, serve well. And apply good relations, so that educational satisfaction is established for students from other countries. Likewise, routine services for visiting foreign guests, teacher exchanges, and so on. The whole process is in an easy, friendly, and responsible manner.

7. The physical evidence

The physical evidence becomes the marketing of mixed standards. They are like symbols directions or directions, views, exterior design signage, and the surrounding environment. Second interior facilities include elements of interior design, equipment used to serve customers 
directly or used to run a business, signage (symbols, directions, instructions), layout, quality of air circulation, and temperature.

Third, Tangibles Other (evidence) other physical). Company physical evidence, business cards, process support stationery, invoices, reports, employee appearances, uniforms, and brochures. In the implementation of evidence, this pesantren has proven its role in international standard programs which include:

-Presidential friends from dozens of countries regularly visit this lodge every year. Countless ambassadors of friendly countries visited this lodge. Even world-class officials and figures such as Tony Blair, Yusuf Al Qordhawi, Imam of the Grand Mosque, Al-Aqsa Mosque, Chancellors of world universities such as Medina, Vice President of Afghanistan, Yusuf Islami and Barrack Obama Advisors and others who cannot be mentioned entirely. Some not only visited but also invited Darunnajah to work together in the field of education.

-International programs are not only enjoyed by pesantren alumni, but also students from the time they are boarding, such as student exchanges, teacher exchanges, and so on. Envoy programs for international events are never-ending from this institution. Not only cooperation with institutions in neighboring countries such as Malaysia and Thailand, but with institutions in countries in the Middle East such as Saudi, Egypt, Qatar or even Australia, even Europe such as the UK

In terms of cooperation in educational programs with foreign institutions, Islamic boarding schools have also made a record that is not less. Recognition of Darunnajah Islamic Boarding School alumni who graduated from various institutions in Middle Eastern countries such as Al Azhar Cairo, Medina Univ in Saudi, International Islamic University Islamabad, and Malaysia. Dozens of alumni each year are dispatched to study at leading universities in the world and so on.

8. The promise

Apart from oaths, some promises must be kept Allah says, to keep a promise is the duty of a Muslim, (al-Maidah: 1) "you who believe swear your promise.it is a sin to break. A promise both verbally and in writing (a letter of agreement). That is the character of Muslim marketers that Allah describes in the Quran. "Fortunate are those who believe, namely those who keep their trust and their promises" (Surah Al-Mu'minun [23]: 1-6). Then it can strengthen the relationship (relationship or silaturrahmi) by keeping promises. If it is associated with this research, physical evidence has also become evidence of a promise, as well as being a promotional medium automatically through word of mouth.

9. The patience

Is one of mixed marketing in Islam. As a symbol and one of the good qualities Muslim marketer. And this is a trait often mentioned in the Quran. Allah Swt says Allah will always be with those who are patient.( surah Al Anfal ayat 46 ayat 46, An nahl ayat 127). Patience means patience in serving customers who give many complaints. Patient in handling problem of marketing, patient in hearing and giving specification information friendly to customers.

If it is associated with this research, the international standard program process is not easy. It takes time and preparation for the program to run smoothly. Even the costs of course must be prepared carefully. All of this course requires patience until the program runs smoothly. Until now the program has been running for quite a long time and many.

10. The customer centrism

Considering the customer as the focal point of marketing theory, the fulfillment of customer needs and wants is the core of marketing practice. According to Islamic teachings, fulfilling needs and wants by offering useful products or services by the Qur'an and Sunnah. If it is related to this research, the focus of the international standard program remains on the students as 
customer-centric who will be involved in facing global competition.

\section{Result and Discussion}

This international standard program was based as a form of building the widest possible network, including supporting the government's plan to make Indonesia a center for international Islamic studies. So it must be marketable. If it is related to this research, in integrated marketing communication the emphasis is on the element of physical evidence, as evidence of recognition from foreign countries, without having to write an international boarding school in its promotion. This is more capable of building trust than massive selfpromotion. People will hear through word of mouth as evidence. This means that the promotion has been built through physical evidence. So that physical evidence becomes a promotional medium through the help of outside parties/other institutions as well.

\section{Conclusion}

Integrated marketing communication is more emphasized on physical evidence so that it will be a strong and very marketable promotion with a focus on customer centrism. Suggestion, pesantren can still use international labels through digital advertising to make it affordable for those who don't know.

Acknowledgements. Are given to all parties who helped carry out this research to completion.

\section{References}

[1] Sampoerna Academy, "Kenali Sekolah Bertaraf Internasional," https://www.sampoernaacademy. sch.id/id/kenali-lebih-lanjut-sekolah-internasional-di-indonesia/, 2021. .

[2] "Pengertian Sekolah Berstandar Internasional," http://eprints.uny.ac.id/9368/2/bab\%202\%20NIM. $\% 2006101244010$.pdf.

[3] Mariati, "MENYOAL PROFIL SEKOLAH BERTARAF INTERNASIONAL," https://jurnaldikbud.kemdikbud.go.id/index.php/jpnk/article/view/386, 2007.

[4] "Kegiatan internasional Darunajah," https://darunnajah.com/pesantren-rasainternasional//\%0A\%0A, 2019. [Online]. Available: https://darunnajah.com/pesantren-rasainternasional/\%\%0A\%0A.

[5] Felinda Karela, "Strategi Pemasaran Sekolah dalam Peningkatan Minat Peserta Didik Berdasarkan Delta Model 2020,” http://etheses.uin-malang.ac.id/11552/1/12710028.pdf, 2020.

[6] Seviyanti Fikroh, "Komunikasi Pemasaran Sekolah Internasional Darul Hikam (Studi Kasus Sekolah Internasional Darul Hikam dalam Mencapai Target Jumlah Murid Baru) 2016.," https://docplayer.info/147977560-Komunikasi-pemasaran, 2016.

[7] A. Pradito, "Penelitian Aditio Strategi Pemasaran," http://ejournal.radenintan.ac.id/index.php /idaroh/, 2016.

[8] Argenti et all, “The strategic communication imperative. MIT Sloan Management Review," https:// sloanreview.mit.edu/article/the-strategic-communication-imperative/, 2005.

[9] Halallan et all, "International Journal of Strategic Communication Publication," https://sloanreview .mit.edu/article/the-strategic-communication-imperative/, 2007. 
[10] K. Lane, manajemen Pemasaran, 12th ed. Jakarta: PT Indeks, 2008.

[11] Yordan Wivan, "KESENJANGAN KARAKTERISTIK ANTAR GENERASI DALAM PENDIDIKAN DI ERA REVOLUSI INDUTRI 4.0," http//eprints.ums.ac.id/80139/2/NASKAH Publ. YORDAN WIVAN L100140064.pdf, 2019.

[12] Nur Asnawi dan M. Asnan Fanani, Pemasaran Syariah. Depok: Rajawali Press, 2017. 